\title{
POSITIVE FEED-BACK EFFECT OF PROGESTERONE ON THE RELEASE OF FSH AND THE INFLUENCE OF SEX IN RATS
}

\author{
S. TALEISNIK, L. GALIGARIS AND J. J. ASTRADA \\ Instituto de Investigación Médica, \\ Mercedes y Martín Ferreyra, ${ }^{*}$ \\ Córdoba, Argentina
}

(Received 28th April 1969)

\begin{abstract}
Summary. Plasma FSH activity (as measured by the ovarian augmentation test in mice) was increased in gonadectomized male and female rats. A single injection of $20 \mu \mathrm{g}$ oestradiol benzoate (OB) or one or two doses of $2.5 \mathrm{mg}$ testosterone propionate (TP) 3 days later reduced the raised values significantly. Progesterone injected into spayed rats, primed 3 days before with $\mathrm{OB}$ or TP, induced, a few hours later, a significant increase in plasma FSH. By contrast, in male rats progesterone failed to exert a positive feed-back effect on the release of FSH. This sex difference was suppressed by the injection of testosterone into female rats on the 4th day of life. In male rats castrated soon after birth, progesterone showed a tendency to increase the activity of FSH in plasma in animals primed either with $\mathrm{OB}$ or $\mathrm{TP}$, but the difference of the values as compared to the controls did not reach the level of significance. It is concluded that the sex difference of the positive feed-back effect of progesterone on the release of FsH could be due to a post-natal differentiation of a neural mechanism.
\end{abstract}

\section{INTRODUCTION}

It has recently been reported (Caligaris, Astrada \& Taleisnik, 1968) that progesterone injected into ovariectomized rats primed with oestrogen promotes a release of luteinizing hormone ( $\mathbf{L H})$. This stimulating effect was shown to be sex-dependent (Taleisnik, Caligaris \& Astrada, 1969). In order to extend this study to the effect of progesterone on follicle-stimulating hormone (FSH) release, the experiments reported in this paper were undertaken.

\section{MATERIALS AND METHODS}

Donor animals were prepared in a similar way to that reported in a previous study on the positive feed-back effect of progesterone on LH release (Taleisnik

* Supported by Grant III f from the Consejo Nacional de Investigaciones Cientifica y Técnicas of Argentina. 
et al., 1969). Adult, albino rats, weighing 220 to $350 \mathrm{~g}$, were used. The animals had either been gonadectomized when adult or on the first day of life, and were kept under natural lighting conditions, to be used 2 to 6 months later.

To study the positive feed-back effect of progesterone on the release of FSH, the gonadectomized animals were primed either with a single subcutaneous (s.c.) dose of $20 \mu \mathrm{g}$ oestradiol benzoate (OB) or with $2.5 \mathrm{mg}$ testosterone propionate (TP). Three days later, $2 \mathrm{mg}$ of progesterone was injected s.c. at 12.00 hours. The animals were bled by heart puncture at 17.00 to 17.30 hours and 4 to $6 \mathrm{ml}$ of blood were taken into a heparinized syringe from each rat. Blood from five to seven donors of each group was pooled and centrifuged and the plasma was separated and frozen at $-20^{\circ} \mathrm{C}$ for 1 to 7 days before use for FSH determination. The steroids were appropriately diluted in peanut oil so that the final volume injected was $0.2 \mathrm{ml}$.

The plasma was tested for FSH activity by the ovarian weight augmentation test in 21- to 23-day-old mice (Brown, 1955). Each recipient animal was injected s.c. with $3 \mathrm{ml}$ of plasma to which 20 i.u. of HCG were added. The total volume was administered in three daily injections over 3 days, and on the 4th day the ovaries were removed, freed from adherent fat and connective tissue and weighed to the nearest $0.05 \mathrm{mg}$. The ovarian weight was expressed in $\mathrm{mg} / 10 \mathrm{~g}$ body weight. Both control and experimental plasma were tested at the same time to eliminate the day-to-day variations in the mouse sensitivity as a factor in the results. Significance of difference between groups was calculated by Student's $t$ test.

The following groups of animals were studied: (a) rats of both sexes gonadectomized when adult; (b) male rats castrated within the first $24 \mathrm{hr}$ after birth; and (c) female rats injected s.c. with $1.25 \mathrm{mg}$ testosterone propionate at 4 days of age. In this last group, only those rats showing persistent cornification in the vaginal smear were spayed and used as experimental animals.

\section{RESULTS}

\section{Use of plasma as test material}

Text-figure 1A shows the results of two experiments in which the influence of plasma as solvent for the gonadotrophins was studied on ovarian response. A higher response was obtained in animals which received the gonadotrophins dissolved in $3 \mathrm{ml}$ of plasma than in those injected with the hormones dissolved in $3 \mathrm{ml}$ of $0.9 \%$ sodium chloride.

To see whether there is a dose-response effect of the test material, plasma from rats which had been castrated for some time was assayed at two dose levels. Three $\mathrm{ml}$ of plasma were used in one dose level and $1.5 \mathrm{ml}$ made up to $3 \mathrm{ml}$ with plasma from normal male rats in the other one. A control group was injected with $3 \mathrm{ml}$ of plasma from normal male rats. As is shown in Text-fig. 1B, a dose-response effect of plasma from gonadectomized rats was found in two assays. The slope of lines (b) was 9.09 and 4.90 and the index of precision (d), $0 \cdot 162$ and $0 \cdot 265$ for each assay. 
Effect of gonadectomy and injection of gonadal steroids

Detectable levels of FsH were found in plasma from gonadectomized male and female rats, but no difference between the sexes was found (Table 1). Plasma from androgenized female rats spayed when adult or from male rats castrated soon after birth presented a similar FSH activity to that found in normal animals gonadectomized when adult.

A single injection of $20 \mu \mathrm{g}$ OB or of $2.5 \mathrm{mg} \mathrm{TP}$ into castrated male rats

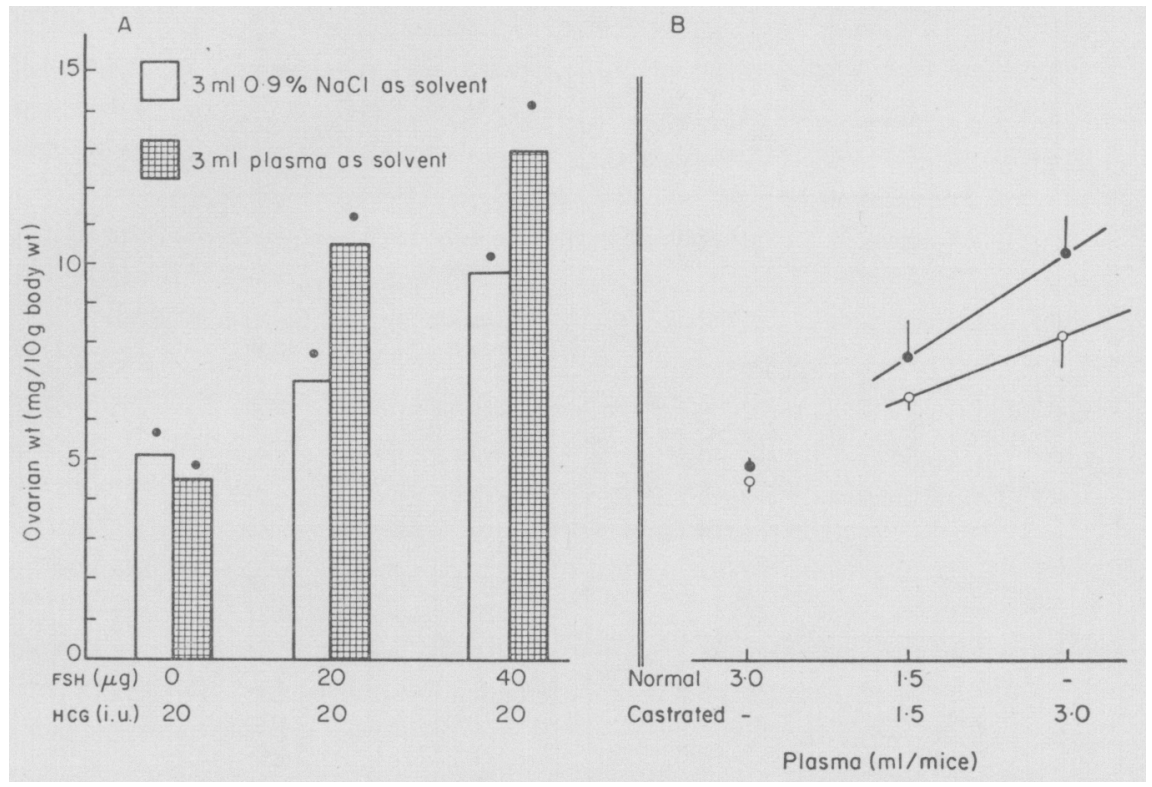

Text-Fig. 1. A. The effect of plasma as a solvent for gonadotrophins in the response to FSH. Doses of 0 and $20 \mu \mathrm{g}$ PSH were studied in one experiment and a dose of $40 \mu \mathrm{g}$ in a second experiment. The columns represent the mean values of five mice injected and the points represent the S.E.

B. The dose-response effect of plasma from castrated rats. Each point is the mean value of five mice and the vertical lines represent the S.E. Open and closed circles refer to two different experimental groups.

reduced the high Fsh plasma values (Table 1 and control groups of Table 2). In spayed female rats, oestrogen was as effective as in the males but the single dose of testosterone did not reduce the elevated values when tested 3 days later. When two doses of testosterone were given, 5 and 3 days before FSH determination, a significant decrease was observed (Table 2).

In androgenized, spayed female rats, a single injection of oestrogen or testosterone was effective in lowering FSH activity in plasma (Table 1 and control groups of Table 3 ) while in males castrated at birth, two doses of the steroids were necessary to depress the elevated values (Table 1 and control groups of Table 4).

Effect of progesterone injected into gonadectomized rats primed with oestrogen or testosterone

In normal ovariectomized rats, primed 3 days before with a single dose of 
$\mathrm{OB}$, the injection of progesterone resulted in a significant increase in plasma FSH when measured $5 \mathrm{hr}$ later. The mean ovarian weight obtained by injecting three pools of plasma was $8.9 \pm 0.4 \mathrm{mg} / 10 \mathrm{~g}$ body weight as compared to $6.7 \pm 0.1 \mathrm{mg} / 10 \mathrm{~g}$ body weight in the controls; the difference was highly significant (Table 2).

The injection of progesterone also produced an increase in plasma FSH in the ovariectomized rats when primed with $\mathrm{TP}$, but the difference as compared to the control group was statistically not significant (Table 2). Since the single

TABLE 1

EFFECT OF GONADECTOMY ON PLASMA FSH IN MALE AND FEMALE RATS

\begin{tabular}{c|c|c|c}
\hline \multirow{2}{*}{ Assay no. } & \multicolumn{3}{|c|}{ Ovarian wt in $\mathrm{mg} / 10 \mathrm{~g}$ body wt (Means \pm S.E.) } \\
\cline { 2 - 4 } Male rats & Normal & $\begin{array}{c}\text { Castrated } \\
\text { adult }\end{array}$ & $\begin{array}{c}\text { Castrated } \\
\text { at birth }\end{array}$ \\
\hline 1 & $5 \cdot 5 \pm 0 \cdot 3(4)$ & $7 \cdot 8 \pm 0 \cdot 1(6)$ & $8 \cdot 6 \pm 0 \cdot 4(6)$ \\
2 & $4 \cdot 9 \pm 0 \cdot 5(5)$ & $7 \cdot 4 \pm 0 \cdot 5(6)$ & $7 \cdot 9 \pm 0 \cdot 6(5)$ \\
3 & $4 \cdot 9 \pm 0 \cdot 2(6)$ & $8 \cdot 6 \pm 0 \cdot 6(7)$ & $8 \cdot 1 \pm 0 \cdot 4(4)$ \\
Overall mean & $5 \cdot 0 \pm 0 \cdot 2(15)$ & $7 \cdot 9 \pm 0 \cdot 2(19)$ & $8 \cdot 2 \pm 0 \cdot 3(15)$ \\
\hline & & & \\
Female rats & Normal & Normal & Androgenized \\
& & spayed & spayed \\
\hline 1 & $5 \cdot 7 \pm 0 \cdot 8(4)$ & $9 \cdot 2 \pm 0 \cdot 5(6)$ & $7 \cdot 5 \pm 0 \cdot 3(8)$ \\
2 & $5 \cdot 0 \pm 0 \cdot 2(4)$ & $8 \cdot 1 \pm 0 \cdot 2(8)$ & $8 \cdot 1 \pm 0 \cdot 5(5)$ \\
3 & $5 \cdot 2 \pm 0 \cdot 3(5)$ & $8 \cdot 1 \pm 0 \cdot 7(7)$ & $7 \cdot 3 \pm 0 \cdot 4(4)$ \\
Overall mean & $5 \cdot 3 \pm 0 \cdot 3(13)$ & $8 \cdot 4 \pm 0 \cdot 3(21)$ & $7 \cdot 6 \pm 0.2(17)$ \\
\hline
\end{tabular}

Number of recipients in parentheses.

dose of testosterone was not effective in reducing the elevated values found in the spayed animals, testosterone was given twice, 5 and 3 days before the test. Under such conditions, progesterone, injected in three groups of animals, induced a significant increase of FSH in the plasma. The overall mean value for FSH in the animals primed with testosterone showed significantly higher values in the animals injected with progesterone than in the control animals (Table 2).

By contrast, no increase of FSH in plasma was observed after the injection of progesterone in castrated male rats, primed with either a single or a double dose of oestrogen or testosterone (Table 2).

Effect of testosterone injection in the early post-natal period in female rats on the response to progesterone

Table 3 summarizes the results of the effect of progesterone injected into androgenized female rats which had been spayed when adult. Contrary to what was observed in normal female rats, the injection of progesterone failed to increase FSH in the plasma of these animals primed either with oestrogen or testosterone. 
Effect of neonatal castration of male rats on the response to progesterone

Table 4 shows the influence of castration during the first day of life on the response of plasma FSH to progesterone. No significant increase in FSH content

TABLE 2

EFFECT OF PROGESTERONE ON PLASMA FSH IN MALE AND FEMALE RATS GONADECTOMIZED WHEN ADULT AND PRIMED WITH GONADAL STEROIDS

\begin{tabular}{|c|c|c|c|c|}
\hline \multirow[t]{2}{*}{ Experiments } & \multirow{2}{*}{$\begin{array}{l}\text { Priming } \\
\text { steroid }\end{array}$} & \multicolumn{2}{|c|}{$\begin{array}{c}\text { Ovarian wt in } \mathrm{mg} / 10 \mathrm{~g} \text { body wt } \\
(\text { Means } \pm \text { S.E. })\end{array}$} & \multirow[t]{2}{*}{$\mathrm{P}$} \\
\hline & & Control groups & $\begin{array}{l}\text { Progesterone } \\
\text { injected }\end{array}$ & \\
\hline $\begin{array}{c}\text { Female rats } \\
\text { A1 } \\
2 \\
3 \\
\text { Overall mean }\end{array}$ & $\mathrm{OB}$ & $\begin{array}{l}6.5 \pm 0.4(4) \\
6.1 \pm 0.2(6) \\
7.9 \pm 0.7(5) \\
6.7 \pm 0.1(15)\end{array}$ & $\begin{array}{l}8 \cdot 4 \pm 0.6(5) \\
8 \cdot 5 \pm 0.6(6) \\
9 \cdot 8 \pm 0.7(5) \\
8.9 \pm 0.4(16)\end{array}$ & $<0.001$ \\
\hline $\begin{array}{c}\text { B1 } \\
2 \\
3 \\
\text { Overall mean }\end{array}$ & $\mathrm{TP}$ & $\begin{array}{l}8 \cdot 6 \pm 0.6(5) \\
7.5 \pm 0.8(4) \\
8 \cdot 6 \pm 0.7(5) \\
8 \cdot 1 \pm 0.4(14)\end{array}$ & $\begin{array}{c}8 \cdot 6 \pm 1 \cdot 2(5) \\
10 \cdot 2 \pm 0 \cdot 7(5) \\
9 \cdot 1 \pm 0 \cdot 6(6) \\
9 \cdot 3 \pm 0.5(16)\end{array}$ & NS \\
\hline $\begin{array}{c}\mathrm{Gl} \\
2 \\
3 \\
\text { Overall mean }\end{array}$ & TPTP & $\begin{array}{l}6 \cdot 6 \pm 0.4(5) \\
7 \cdot 4 \pm 0.6(6) \\
5 \cdot 1 \pm 0.4(5) \\
6.4 \pm 0.4(16)\end{array}$ & $\begin{array}{c}10 \cdot 0 \pm 0.3(5) \\
6.9 \pm 0.4(6) \\
6.9 \pm 0.9(5) \\
7 \cdot 9 \pm 0.5(16)\end{array}$ & $<0.05$ \\
\hline $\begin{array}{l}\text { Overall mean of } \\
\text { TP-primed rats }\end{array}$ & & $7 \cdot 2 \pm 0 \cdot 3(30)$ & $8 \cdot 6 \pm 0 \cdot 4\langle 32\rangle$ & $<0.01$ \\
\hline $\begin{array}{c}\text { Male rats } \\
\mathrm{D} 1 \\
2 \\
\text { Overall mean }\end{array}$ & OB & $\begin{array}{l}6.9 \pm 0.7(4) \\
7.4 \pm 0.5(5) \\
7.2 \pm 0.5(9)\end{array}$ & $\begin{array}{l}6.4 \pm 0.5(5) \\
7.6 \pm 0.7(5) \\
7.0 \pm 0.4(10)\end{array}$ & NS \\
\hline E1 & ОВОВ & $7 \cdot 2 \pm 0 \cdot 2$ & $6 \cdot 2 \pm 0.4(5)$ & NS \\
\hline $\begin{array}{l}\text { Overall mean of } \\
\text { OB-primed rats }\end{array}$ & & $7 \cdot 2 \pm 0.3(14)$ & $6 \cdot 7 \pm 0.3(15)$ & NS \\
\hline $\begin{array}{c}F 1 \\
2 \\
3 \\
\text { Overall mean }\end{array}$ & $\mathrm{TP}$ & $\begin{array}{l}7 \cdot 1 \pm 0.4(5) \\
6.4 \pm 0.3(5) \\
6.4 \pm 0.6(6) \\
6.6 \pm 0.3(16)\end{array}$ & $\begin{array}{l}6.4 \pm 0.6(4) \\
6 \cdot 2 \pm 0.4(5) \\
7.5 \pm 0.5(5) \\
6.9 \pm 0.1(14)\end{array}$ & NS \\
\hline G1 & ТРТP & $6 \cdot 4 \pm 0 \cdot 4(5)$ & $6 \cdot 4 \pm 0 \cdot 3(6)$ & NS \\
\hline $\begin{array}{l}\text { Overall mean of } \\
\text { TP-primed rats }\end{array}$ & & $6.6 \pm 0.2(21)$ & $6 \cdot 7 \pm 0.2(20)$ & NS \\
\hline
\end{tabular}

Number of recipients in parentheses.

$\mathrm{OB}=$ oestradiol benzoate. $\mathrm{OBOB}=$ oestradiol benzoate 5 and 3 days before progesterone. $\mathrm{TP}=$ testosterone propionate. $\mathrm{TPTP}=$ testosterone propionate 5 and 3 days before progesterone. NS = non-significant.

in plasma was observed after the injection of progesterone into oestrogenprimed animals using either one or two doses of the priming steroid, nor was there a significant increase when the animals were primed with testosterone. However, despite the lack of significant differences between controls and animals injected with progesterone, the mean values of the different groups show a consistent tendency of plasma FSH to increase after progesterone injection. 
TABLE 3

RELEASE OF FSH INDUCED BY PROGESTERONE IN ANDROGENIZED FEMALE RATS OVARIEGTOMIZED WHEN ADULT

\begin{tabular}{|c|c|c|c|c|}
\hline \multirow[t]{2}{*}{ Experiments } & \multirow{2}{*}{$\begin{array}{l}\text { Priming } \\
\text { steroid }\end{array}$} & \multicolumn{2}{|c|}{$\begin{array}{c}\text { Ovarian wt in } m g / 10 g \text { body wt } \\
(\text { Means } \pm S . E .)\end{array}$} & \multirow[t]{2}{*}{$\mathbf{P}$} \\
\hline & & Control group & $\begin{array}{l}\text { Progesterone- } \\
\text { injected }\end{array}$ & \\
\hline $\begin{array}{c}\mathrm{Al} \\
2 \\
\text { Overall mean }\end{array}$ & OB & $\begin{array}{l}5 \cdot 2 \pm 0 \cdot 2(6) \\
6 \cdot 3 \pm 0 \cdot 1(5) \\
5 \cdot 7 \pm 0 \cdot 1(11)\end{array}$ & $\begin{array}{l}5 \cdot 3 \pm 0.3(5) \\
6 \cdot 8 \pm 0.4(5) \\
6 \cdot 1 \pm 0.4(10)\end{array}$ & NS \\
\hline $\begin{array}{c}\text { B1 } \\
2 \\
\text { Overall mean } \\
\quad \text { C1 } \\
\text { Overall mean of } \\
\text { TP-primed rats }\end{array}$ & TPTP & $\begin{array}{l}7 \cdot 1 \pm 0.5(5) \\
5.9 \pm 0.1(6) \\
6.5 \pm 0.3(11) \\
5.5 \pm 0.3(6) \\
6 \cdot 1 \pm 0.3(17)\end{array}$ & $\begin{array}{l}6.3 \pm 0.1(6) \\
5.8 \pm 0.4(6) \\
6.0 \pm 0.1(12) \\
4.9 \pm 0.2(6) \\
5.7 \pm 0.2(18)\end{array}$ & $\begin{array}{l}\text { NS } \\
\text { NS } \\
\text { NS }\end{array}$ \\
\hline
\end{tabular}

Conventional abbreviations as for Table 2.

TABLE 4

EFFECT OF PROGESTERONE ON PLASMA FSH IN MALE RATS GASTRATED AT BIRTH

\begin{tabular}{|c|c|c|c|c|}
\hline \multirow[t]{2}{*}{ Experiments } & \multirow{2}{*}{$\begin{array}{l}\text { Priming } \\
\text { steroid }\end{array}$} & \multicolumn{2}{|c|}{$\begin{array}{c}\text { Ovarian wt in } m g / 10 g \text { body wt } \\
(\text { Means } \pm S . E .)\end{array}$} & \multirow[t]{2}{*}{$\mathbf{P}$} \\
\hline & & Control group & $\begin{array}{l}\text { Progesterone- } \\
\text { injected }\end{array}$ & \\
\hline $\begin{array}{c}\text { A1 } \\
2 \\
3 \\
\text { Overall mean }\end{array}$ & $\mathrm{OB}$ & $\begin{array}{l}7.3 \pm 0.3(5) \\
7.8 \pm 0.8(5) \\
8.0 \pm 0.5(5) \\
7.7 \pm 0.3(15)\end{array}$ & $\begin{array}{l}7.4 \pm 0.4(5) \\
9 \cdot 1 \pm 0.9(5) \\
9.0 \pm 0.8(5) \\
8.5 \pm 0.4(15)\end{array}$ & \multirow[t]{3}{*}{ NS } \\
\hline $\begin{array}{c}\text { B1 } \\
2 \\
3 \\
\text { Overall mean }\end{array}$ & \multirow[t]{2}{*}{ OBOB } & $\begin{array}{l}7.5 \pm 0.2(3) \\
4.8 \pm 0.3(5) \\
6 \cdot 7 \pm 0.7(5) \\
6.2 \pm 0.4(13)\end{array}$ & $\begin{array}{l}8.9 \pm 0.5(6) \\
5.4 \pm 0.6(5) \\
6 \cdot 2 \pm 0.3(5) \\
7 \cdot 0 \pm 0.5(16)\end{array}$ & \\
\hline $\begin{array}{l}\text { Overall mean of } \\
\text { OB-primed animals }\end{array}$ & & $7.0 \pm 0.3(28)$ & $7 \cdot 7 \pm 0.4(31)$ & \\
\hline $\begin{array}{c}\mathrm{Cl} \\
2 \\
3 \\
\text { Overall mean }\end{array}$ & $\mathbf{T P}$ & $\begin{array}{l}8.4 \pm 0.8(5) \\
6.2 \pm 0.5(5) \\
8.2 \pm 0.8(4) \\
7.7 \pm 0.5(14)\end{array}$ & $\begin{array}{l}9.4 \pm 0.7(5) \\
8 \cdot 6 \pm 0.4(6) \\
6 \cdot 9 \pm 0.4(5) \\
8.3 \pm 0.4(16)\end{array}$ & \multirow[t]{3}{*}{ NS } \\
\hline $\begin{array}{c}\text { D1 } \\
2 \\
3 \\
\text { Overall mean }\end{array}$ & TPTP & $\begin{array}{l}6.6 \pm 0.3(5) \\
7.2 \pm 0.5(4) \\
6.9 \pm 0.5(5) \\
6.9 \pm 0.2(14)\end{array}$ & $\begin{array}{l}5 \cdot 8 \pm 0.5(5) \\
9 \cdot 1 \pm 1.0(4) \\
8 \cdot 3 \pm 0.4(6) \\
7 \cdot 6 \pm 0.5(15)\end{array}$ & \\
\hline $\begin{array}{l}\text { Overall mean of } \\
\text { TP-primed animals }\end{array}$ & & $7 \cdot 3 \pm 0.3(28)$ & $8 \cdot 0 \pm 0.3(31)$ & \\
\hline
\end{tabular}

Conventional abbreviations as for Table 2. 


\section{DISCUSSION}

The ovarian augmentation test in mice was shown to be specific for FsH (Brown \& Wells, 1966). The high volume of plasma $(3 \mathrm{ml})$ injected into the animals in the present study may raise doubts about the validity of the test as an index of FsH activity. The fact that the response of mouse ovarian weight to NIH-FSH shows a sensitivity which is even higher when the hormone is dissolved in plasma than when it is in $0.9 \%$ sodium chloride, however, rules out this objection. Furthermore, the injection of plasma has apparently no harmful effect since the animals gain weight normally and do not appear to differ in any way externally from the animals injected with saline. Salhanick (1961) has shown that vehicles inducing delayed absorption increase the sensitivity of the test and plasma could have acted as such a vehicle to elicit a higher ovarian response.

Plasma from gonadectomized rats gave an ovarian response, which was related to the dose injected and the slope and precision of the assay were similar to those reported using purified hormones (Martin \& Peyton, 1967).

No difference was reported in the plasma FSH content of intact male and female rats, as measured by the increase in testicular weight in hypophysectomized hemicastrated animals (Gans \& de Jongh, 1963). However, using the augmentation test of testis weight in hypophysectomized immature rats, the serum of intact male rats was found to be more active than that of females (Gans \& van Rees, 1966). Johnson (1967) also showed a significantly greater amount of circulating FSH in intact males when measured by the method of parabiosis. In gonadectomized animals, there is an increase in plasma FSH content and higher levels were found in castrated males than in spayed females (Gans, 1959; Gans \& de Jongh, 1963). Parlow (1964), on the contrary, did not observe any sex difference using the Steelman and Poley method. The results of the present work are in agreement with the last author; no difference was found in the FSH content of the plasma of male and female gonadectomized rats; nor did the treatment of females with testosterone in the early post-natal period or the castration of males on the 1st day of life have any influence on FSH content. Johnson \& Witschi (1963a,b) observed, by the parabiotic technique, that the removal of the ovaries from androgenized female rats resulted in an increase of circulating FsH but the levels were probably subnormal. Gans \& de Jongh (1963), on the other hand, reported that the higher levels of FSH in castrated males, as compared to spayed females, were maintained even if gonadectomy was carried out on the 1st day of life.

The results of the current work show that oestrogen or testosterone injected into gonadectomized animals is effective in depressing the elevated FsH content in plasma. Even though the technique which has been used is not the most convenient for studying sex difference sensitivity to gonadal steroids, the fact that after a single dose of testosterone, a decrease in plasma FSH was found in the male but not in the female rats suggests that castrated male rats may be more sensitive than spayed female rats to the negative feed-back of testosterone. Gans (1959) reported that testosterone decreased serum FSH more effectively in male than in female rats. Furthermore, the androgenized female rats showed a 
greater sensitivity to the single dose of testosterone than did the normal female rats and similar results have been described for the release of $\mathbf{L H}$ (Boyd \& Johnson, 1968).

The results of the present study indicate that release of FSH can be induced by the injection of progesterone in female rats when they are primed either with oestrogen or testosterone. A clear sex difference in the positive feed-back effect of progesterone on FSH release was observed since no response was obtained in male rats. The pattern of FSH release determined by progesterone is, to some extent, different from that of $\mathbf{L H}$ release. In fact, it has been demonstrated (Taleisnik et al., 1969) that while a significant increase in plasma LH takes place after the injection of progesterone in female rats primed either with oestrogen or testosterone, in male rats this effect is only observed when the animals have been primed with testosterone. Consequently, a dissociate effect of progesterone on the release of LH and FSH is observed in male rats primed with testosterone. A similar dissociate effect of copulation has been reported (Taleisnik, Caligaris \& Astrada, 1966).

Testosterone injected in female rats in the early post-natal period was found to alter the neural mechanism by which progesterone provokes release of FSH. In fact, the response to progesterone observed in the normal animal is abolished in the androgenized female rat. Since progesterone is still effective in inducing release of LH in these animals primed with oestrogen (Taleisnik et al., 1969), the presence of testosterone soon after birth seems to have a greater effect on the neural mechanism concerned with FSH release at this time.

Since testosterone injected in the early neonatal period of female rats was effective in inducing a male pattern of FsH release, it was pertinent to remove the endogenous source of testosterone from the male to see to what extent this steroid is responsible for that pattern. It has been shown that, if a male rat is castrated at birth and an ovary is implanted, corpora lutea are formed, contrary to what is found if the animals are castrated when adult (Harris, 1964; Pfeiffer, 1936; Takewaki, 1962). This would indicate that the absence of testosterone in the early post-natal period avoids fixing the neural pattern characteristic of the male and preserves that present in the female. The results of the current work show that even though in male rats castrated on the 1st day of life, no significant increase in plasma FSH was observed after the injection of progesterone, as was found in female rats, there is a tendency to increase in all the groups which have been studied. Moreover, some of the individual assays gave significant differences between the progesterone-injected and the control groups. These facts suggest that the removal of the testis soon after birth tends to avoid the establishment of a male pattern for the neural mechanism by which progesterone provokes release of FSH.

The studies on sex difference in the release of gonadotrophins were based almost exclusively on the capacity of the animals to form corpora lutea in their own ovaries or in transplanted ones. The results of the current work and of work previously reported (Taleisnik et al., 1969) suggest that the circumstances under which corpora lutea are formed, contrary to what might be presumed, are more related to the capacity of the animals to release FSH than to release $\mathrm{LH}$ following the injection of progesterone. 


\section{ACKNOWLEDGMENTS}

This work was supported by the United States Public Health Service Grant NB 04732-04. HCG was generously provided by Elea, Laboratorio Endocrínico Argentino, Buenos Aires. FSH was a gift from the Endocrine Study Section, The National Institutes of Health, U.S.A.

\section{REFERENCES}

Boyd, R. \& Jornson, D. C. (1968) Gonadotrophin patterns in male and female rats: inhibition of LH release by testosterone propionate in animals gonadectomized at puberty. Acta endocr., Copenh. 58,600 .

Brown, P. S. (1955) The assay of gonadotrophin from urine of non-pregnant human subjects. $\mathcal{F}$. Endocr. 13, 59.

BRown, P. S. \& WeLLS, M. (1966) Observations on the assay of human urinary follicle-stimulating hormone by the augmentation test in mice. F. Endocr. 35, 199.

Caligaris, L., Astrada, J. J. \& Taleisnik, S. (1968) Stimulating and inhibiting effects of progesterone on the release of luteinizing hormone. Acta endocr., Copenh. 59, 177.

GANS, E. (1959) The FSH-content of serum of intact and of gonadectomized rats and of rats treated with sex hormones. Acta endocr., Copenh. 32, 362.

Gans, E. \& DE Jongh, S. E. (1963) Factors determining the sex differences in pituitary and serum FsH content after gonadectomy. Acta endocr., Copenh. 43, 323.

Gans, E. \& van Rees, G. P. (1966) Studies on the testicular augmentation assay method for follicle stimulating hormone. Acta endocr., Copenh. 52, 573.

Harris, G. W. (1964) Sex hormones, brain development and brain function. Endocrinology, 75, 627.

Jornson, D. C. (1967) Gonadotrophin patterns in male and female rats: plasma LH and FsH at various ages evaluated by the method of parabiosis. Acta endocr., Copenh. 56, 165.

Johnson, D. C. \& Witschi, E. (1963a) Hypophyseal gonadotrophins following gonadectomy in male and female androgenized rats. Acta endocr., Copenh. 44, 119.

Johnson, D. C. \& Witschi, E. (1963b) Effect of follicle-stimulating hormone, chorionic gonadotropin and estradiol in androgenized female rats. Endocrinology, 74, 467.

Martin, F. I. R. \& Peyton, L. (1967) The specificity of the mouse ovarian augmentation assay for follicle stimulating hormone. Acta endocr., Copenh. 56, 359.

Parlow, A. F. (1964) Comparison of pituitary and serum gonadotrophins of the rat. Endocrinology, 74, 489.

Pfeiffer, C. A. (1936) Sexual differences of the hypophyses and their determination by the gonads. Am. F. Anat. 58, 195.

Salhanick, H. A. (1961) Bio-assay procedure for determination of HPG. In: Human Pituitary Gonadotropins, pp. 90-100. Ed. A. Albert. Thomas, Springfield, Ill.

TAKEWAKI, K. (1962) Some aspects of hormonal mechanism involved in persistent estrus in the rat. Experientia, 18, 1.

Taleisnik, S., Caligaris, L. \& Astrada, J. J. (1966) Effect of copulation on the release of pituitary gonadotropins in male and female rats. Endocrinology, 79, 49.

Taleisnik, S., Caligaris, L. \& Astrada, J. J. (1969) Sex differences in the release of luteinizing hormone evoked by progesterone. F. Endocr. 44, 313. 